\title{
Energy Efficient Cooling Technologies for Achieving Sustainability in Buildings in Subtropical Climate
}

\author{
Ashfaque Ahmed Chowdhury, Central Queensland University, Queensland, \\ AUSTRALIA \\ M.G. Rasul, Central Queensland University, Queensland, AUSTRALIA \\ M.M.K. Khan, Central Queensland University, Queensland, AUSTRALIA
}

\begin{abstract}
Energy efficient cooling technology is the key to the building's sustainability. To approach the concept of energy efficiency in building systems in a sub-tropical climate, buildings should adopt a number of innovative technologies. The building sector is of great consequence in Australia's economy and greatly affects the level of resources that are consumed. As sustainability is an increasingly important issue, there is a need to address the factors affecting sustainability in the building sector. Globally buildings are responsible for a large portion of the total annual energy consumption in the world. Most of this energy is for the functioning of lighting, heating, cooling and air conditioning. Concerns about social and environmental sustainability have led to increased interest in planning for proper utilisation of energy. World's attention on current climate change impact and sustainability has also urged for a closer look at the energy efficient technologies. As buildings are important consumer of energy and thus important contributor to the higher greenhouse gas emissions to the environment. Therefore, low energy cooling technologies for buildings must be one of the definite alternatives to contribute to the sustainability of buildings. This study is a step towards achieving this goal. In this study, the technologies of energy efficiency improvement in building cooling are reviewed to achieve better sustainability. The effectiveness of space-conditioning technologies within the building systems is also discussed.
\end{abstract}

Keywords: Building Sustainability, Energy Efficiency, Sub-Tropical Climate

\section{Introduction}

$\mathrm{T}$ HE TECHNOLOGICAL PROGRESS to the present day offered a series of appreciable changes in the planet. Therefore, environmental protection, social and economic developments become essential to achieve sustainable development (World Business Council for Sustainable Development - WCED, 1987). In recent years, there have been advances in favour of buildings being more environmental friendly. Numerous countries have greater or lesser success launched initiatives to achieve more environmental friendly buildings throughout their life cycle (Todd, et. al., 2001). Therefore, general concept of sustainability in the building sector includes environmental, economic and social concerns.

San-Jose, et, al., (2007) analysed the sustainable environmental requisites by defining the indicators to assess building behaviour and developed an assessment model as a base for measuring the building environmental sustainability index. The concept of sustainable development involves moving towards complying with econo-centric concerns, technocentric concerns and socio-centric concerns. For sustainability, all the three constraints need to meet. Clift (2007) assessed the techno-economic feasibility to reduce emissions of carbon dioxide by $60 \%$ by 2050 in the United Kingdom. The target can be achieved economically if the efficiency of energy use is improved to achieve reduction in demand, combined with a shift to lower carbon energy sources. Climate change is considered to be the major thread. The study showed that the necessary reductions in carbon dioxide emissions could be achieved by known technologies.

Sustainable global aspects to be met by the buildings require a sustainable vision (Lutzkendorf \& Lorenz, 2005). Throughout the useful life of a building, during its use stage, it will have impacts on the environment via electricity consumption. Not only that, from sustainability's view point, co-ordination of resources to be consumed by a building throughout its useful life acquires great importance. This aspect mainly refers to electricity consumption for lighting, ventilation and air conditioning (Sarja, 2002).

The concept of sustainable development and sustainability are integrated to the green building. Effective green building will show the way to reduce operating costs by increasing productivity, by using less energy and by dropping environmental impacts (Wikipedia, 2007). However, the environmental impact of buildings was often underestimated, while

THE INTERNATIONAL JOURNAL OF ENVIRONMENTAL, CULTURAL, ECONOMIC AND SOCIAL SUSTAINABILITY, VOLUME 4, NUMBER 5, 2008

http://www.Sustainability-Journal.com, ISSN 1832-2077

(c) Common Ground, Ashfaque Ahmed Chowdhury, M.G. Rasul, M.M.K. Khan, All Rights Reserved, Permissions: cg-support@commongroundpublishing.com 
the perceived costs of building green were overestimated. A recent survey by the World Business Council for Sustainable Development found that green building costs were overestimated by $300 \%$ - more triple the true average cost difference of about $5 \%$. The Green Building Council of Australia developed a green building standard known as Green Star. In Adelaide, there are at least two projects that incorporate the principles of green building. The Eco-city development is located in Adelaide's city centre and the Aldinga Arts Eco Village is located in Aldinga. Melbourne, another Australian city, is the host of many green buildings and sustainable developments for instance, Centre for Education and Research Environmental Strategies (CERES) Environmental Part and Council House 2 (Wikipedia, 2007).

This study reports the basic efforts towards energy efficient role of Heating, Ventilation and Air Conditioning (HVAC) for ensuring high performance buildings in operation and design for better sustainability. The technologies for effective HVAC systems for subtropical climate are explained and immerging HVAC technologies are described in the rest of the section. It is believed that with integrated and holistic approach to HVAC and building design, performance of existing building can be improved.

\section{Energy Consumption Scenario in Australia}

In Australia, the structure of energy consumption by different consumer groups is characterised by a high share of the building sector. In subtropical climate, the use of air conditioning is progressively growing. In 2002, Australia generated 210.3 billion kilowatthours (bkWh) of electricity and consumed 195.6 bkWh (Chowdhury, et. al., 2006). The Energy Supply Association of Australia (ESAA) has predicted that consumption will grow rapidly in coming years, rising to $206 \mathrm{bkWh}$ by 2008 , with the majority of growth in consumption concentrated in Queensland, New South Wales and Victoria. According to the report published in 2000 by Built Environment Research Unit, Public Works Department, Queensland, Australia; Space Cooling in Queensland's residential and commercial buildings accounts for approximately $32 \%$ of the state's total annual electrical energy consumption.

Increased energy efficiency in buildings can provide financial benefits through reduced electricity bills. Improvements in energy efficiency also play a part in reducing energy use, contribute to the competitiveness, and assist in better managing energy demands and buildings' sustainability. The Queensland Government Energy Management Strategy is a whole-of-Queensland Government energy efficiency initiative. Queensland Government departments use about 860 million kWh of electricity annually, cost- ing approximately $\$ 86$ million. That electricity generates greenhouse gas emissions equivalent to those produced by 909,880 cars. Greenhouse gas emissions are harmful to the environment, contributing to global warming. Australia has officially recorded its warmest year on record. According to annual Australian climate statement 2005, Bureau of Meteorology indicated that the nation's annual mean temperature for 2005 was $1.09^{\circ} \mathrm{C}$ above the standard 1961 1990 average, making it the warmest year since reliable, widespread temperature observations became available in 1910. Despite some regional variations, the warm conditions in 2005 were remarkably widespread. All States and Territories, apart from Victoria and Tasmania, recorded 2005 mean temperatures amongst their top two warmest years on record. Australian temperatures have increased by approximately $0.9^{\circ} \mathrm{C}$ since 1910 , consistent with global warming trends. Therefore, the trend of temperature increase will certainly increase space cooling cost and energy consumption. This is the time to evaluate major energy consuming elements for better sustainability of Australian buildings. The improvement in energy systems of building operating on is an alternative way to reduce greenhouse gas emissions and increase sustainability in buildings.

\section{Energy Efficient Cooling Technologies for Building Sustainability}

For achieving energy efficiency within buildings with better sustainability, a methodology of several steps can be considered towards energy conservation in building. Firstly, it is focused on standard methods of energy efficiency, the second one supports the energy-savings measures and the third one is economical feasibility. Thermal modernisation of old buildings is performed to achieve significant reductions in energy consumption and to improve indoor-climate conditions. The reduction of energy demand in buildings can be achieved by improving building envelope elements, by reducing heat losses in local heat distribution systems and local heat sources etc.

The basic rule for building sustainability will be to introduce standard well-proven energy efficient technologies and then to use new unconventional methods of energy conversion, storage and utilisation, including implementation of renewable energy. The future of sustainability measures in building sector depends on coherency between economics, energy efficiency and environment protection. The idea of sustainability in buildings can be implemented through innovative technologies and measures by using passive solar system for the building itself, by applying day lighting; by integrating solar-active thermal and photovoltaic systems into building; by adding short and long term (seasonal) energy storage 
(e.g. underground thermal energy storage) etc. Utilisation of renewable and wastes in extreme cases leads to self-energy sufficient buildings. These buildings do not require energy to be supplied by external sources; the energy is produced and used at site.

The other types of buildings include intelligent buildings using Building Management Systems (BMS). The main aim of these systems are to control all systems in the building to assure the proper management of the energy demand, to conserve energy, to improve the comfort levels including indoorair quality, and to increase the building's productivity through leveraging information. The idea of integrated building services functions is beneficial from the sustainability point-of-view. In addition, economic viable and embodied energy can be an important issue.

Subtropical climate encompasses a wide range of temperature and humidity conditions. Therefore, most HVAC systems are designed to provide comfort through mechanical cooling. While this traditional approach to cooling can provide acceptable comfort, it does not always do so in climate-responsive or energy-efficient way from sustainability point of view. Effective solar control, appropriate building materials, and internal load minimization (e.g., efficient lights, Energy Star office equipment) can reduce or altogether eliminate the need for mechanical cooling. Eliminating traditional mechanical cooling systems has numerous benefits, including reduced construction cost, lower maintenance requirements, less noise, and significantly lower energy costs. The right combination of approaches and mechanical system approaches can take almost any outdoor weather condition and shift it towards the comfort zone. For buildings, having both operable windows as well as traditional mechanical cooling expand the comfort envelope and minimize potential energy waste. The following strategies are required to enhance energy efficiency and comfort by taking advantage of a climate's characteristics.

\section{Displacement Ventilation (DV)}

Although displacement ventilation, an alternative to conventional mixing system, were used for industrial buildings. Lin, et. al., (2005) investigated the typical office building and found that DV system produced superior indoor air quality. It has designed to minimize mixing of air in the occupied zone and used 2.53 air changes/hour (Schultz, 1993). It is achieved by conditioned air at a lower temperature than desired room temperature and indoor temperature depends upon changes with height. In different studies, ISO 7730 (1995) and Loveday, et. al., (1998) individually suggested air temperature gradient $3 \mathrm{~K} / \mathrm{m}$ as satisfactory for displacement ventilation. By supplying air at $17^{\circ} \mathrm{C}$ instead of $13^{\circ} \mathrm{C}$, displacement ventilation saves on chiller energy compared to usual air conditioning system. It also saves thermal energy compare to traditional air conditioning systems because displacement ventilation maintains room temperature at $23^{\circ} \mathrm{C}$, whereas traditional systems maintain $21^{\circ} \mathrm{C}$. Apparently, it reduces comfort. Comparing the cooling differential index, which is $8 \mathrm{~K}$ and $6 \mathrm{~K}$ for displacement and traditional systems respectively, for same heat load, displacement ventilation requires higher flow rate than traditional systems. Displacement system uses less energy compared to traditional system as because it cannot cope large load and is appropriate for constant small load of $25 \mathrm{~W} / \mathrm{m}$ (Levermore, 2000). In subtropical climate, displacement ventilation can be operated throughout the year with supply air temperature between $18^{\circ} \mathrm{C}$ to $20^{\circ} \mathrm{C}$. Trox (1997) suggested that it can be operated as a variable air volume system. Lin, et., al. (2005) illustrates that displacement system can be affected by imbalance in the heat source within the office space.

\section{Mixed Mode Ventilation}

The term mixed-mode typically describes a system that combines natural and mechanical ventilation. It provides many advantages of natural ventilation, as well as, other benefits like greater control over internal conditions; weather-proof night ventilation; improved ventilation on still nights; the ability to offset higher heat gains where stack ventilation is not possible; greater building flexibility to cope with changes of usage, occupant density, internal loads, etc. For most active systems, a mixed-mode approach is generally preferred to full time mechanical ventilation, which affords building occupants very little control over their environment. Natural ventilation also realises the benefits of free cooling, i.e. ventilation without fans operations because they account for a significant proportion of the energy used in mechanically ventilated buildings. The combination of centralised plant supplying an underfloor ventilation system is particularly an effective format in mixed-mode systems. This solution provides good convective heat transfer with the top of the slab, enabling thermal linking on both sides in buildings with exposed soffits. Centralised air handling plant enables the heat lost by ventilation during the winter to be minimised by incorporating a heat recovery device such as a cross-flow heat exchanger, designed to recover heat from exhaust air to preheat incoming fresh air. During summer nights, a damper controlled bypass prevents the heat recovery device from warming the incoming fresh air. On very hot summer days, the incoming fresh air can be pre-cooled at times when the exhaust air is at a lower temperature. The effectiveness of pre-cooling can be enhanced 
through the addition of evaporative cooling of the exhaust air before it passes through the heat recovery device. These can cool the fresh air without increasing its moisture content, and can lower the supply temperature by several degrees depending on the ambient and internal conditions (Chowdhury, et. al., 2006).

\section{Night Ventilation}

Night ventilation is a technique whereby cool nocturnal air is circulated through the building in order to reduce the temperature of the indoor air and internal building fabric (Geros, et. al., 1998). A number of researchers studied suitable night ventilation processes for cooling offices at different locations. The cooling potential of the night ventilation technique has been experimentally and theoretically studied under different conditions. A simulation model with suitable weather data were used to examine the potential for energy savings and improved internal comfort conditions by applying night ventilation cooling to air-conditioned office buildings (Kolokotroni \& Aronis 1999). The thermal mass and night ventilation reduced the effect of external comfort conditions in two monitored naturally ventilated low energy new office buildings (Kolokotroni, 1998). Through simulation results using the software TRANSYS and full scale experiments, the coupling between night ventilation and mechanical cooling were shown to be an efficient and low-cost way to cool buildings (Blondeau, et. al., 1997). By longterm measurements and analysis, intermittent mechanical ventilation other than the day and night natural ventilation is recommended for residential buildings in hot climates (Fu, et. al., 1996).

The influence of thermal mass and night ventilation on the maximum indoor temperature in a hot humid climate were analysed using an hourly simulation model ENERGY by Shaviv, et. al., (2001) to predict the thermal performance of the building. The study reported that the maximum indoor temperature depended linearly on the temperature difference between the day and night at the site. Becker \& Paciuk (2002) investigated the impact of night ventilation and pre-cooling on peak cooling demand for an office building in a coastal region. In the model used, although only the cooling loads were calculated for a typical summer day, up to $35 \%$ in energy cost savings were achieved. Night ventilation should take maximum advantage of ambient conditions whilst avoiding overcooling, which will result into uncomfortable conditions at the start of the day, and may result in a subsequent need to reheat the space.

\section{Radiant Cooling}

Radiant cooling as an alternative air-conditioning system was first investigated in laboratory studies in European countries in the early 1990s (Wilkins, et. al.,1992 and Niu, et. al., 1995). Then the system started its applications in combination with displacement ventilation systems (Mertz, et. al., 1992 and Niu, et. al., 1994). Radiant cooling with displacement ventilation is more energy efficient compared to conventional air conditioning system (Feustel \& Stetiu, 1995; Imarori, et. al., 1999). In Europe, it is reported that cooling tower could be useful to cool the water for supply to the radiant panel on the ceiling (Facoa \& Oliveria, 2000). In recent years, both simulation studies and experimental research on Hydronic radiant cooling and displacement ventilation have been reported (Loveday, et. al., 2002; Alamdari, et. al., 1998; Rees, et. al., 2001; Mumma, 2001 and Novoselac et al. 2002). Feustal (1995) claimed that cooling would be provided directly and more eventually to the occupants without causing draft.

Radiant cooling systems separate the cooling and ventilation tasks of a building conditioning system, by employing chilled-ceiling to treat cooling load and setting up an independent ventilation system. It is generally believed that radiant system has three main advantages. First, the pump energy required to move heat in a water based system is much lower than fans in an air-based system. Second, radiant systems improve thermal comfort because heating and cooling are provided directly and more evenly to the occupants without causing drafts. Third, simple and effective zone control is provided. Because of these reasons, it can be employed in subtropical climate. As a passive cooling alternative radiant cooling has higher potential for energy and peak savings. Applications of radiant cooling to subtropical regions are much more necessary.

Chilled ceiling (CC) has become a popular choice due to its characteristics of good thermal comfort, high air quality, low energy consumption and high ventilation effectiveness. Udagawa (1993) developed a linear subsystem model considering a generalized simulation algorithm of a room's thermal environment and the energy efficiency of radiant cooling system. Feustel \& Stetiu (1995) have investigated the performance of radiant cooling with a chilled ceiling system. The system was employed with the aim of reducing the amount of electrical energy used to cool non-residential buildings equipped with allair systems, using fans that transport the cool air through the thermal distribution system. Stetiu, et. al. (1995) developed a model to simulate the performance of a radiant cooling ceiling system and found that radiant cooling reduces the energy consumption and peak power requirement of the air-conditioning 
system. Kilkis (1995) developed a computer program using a quasi-steady state heat transfer model for design and analysis of chilling panels. The results showed that the success of a panel cooling system depended on careful analysis of anticipated indoor conditions and appropriate design. Sulzer Infra Lab Ltd. and Swiss Federal Institute for Materials Testing and Research carried out research aimed at optimizing the energy efficiency of a chilled ceiling by means of calculation and testing (Sprecher, et. al., 1996). Niu, et. al., (1997) described the cooling load dynamics and annual energy consumption of rooms with cooled ceiling systems by using the dynamic building thermal analysis program.

The origination and development of chilled ceiling, displacement ventilation and combined system reviewed by Riffat, et. al., (2004) and current status were explained with a view to determine the design consideration. Ghali, et. al., (2007) studied the design and performance of a cooled ceiling and displacement ventilation system application for buildings in humid climates for the purpose of energy savings, better indoor air quality and thermal comfort. The study confirmed that a chilled ceiling system consumed $21 \%$ less cooling energy than the conventional $100 \%$ fresh air system over the cooling season. Although the initial cost is high for $\mathrm{CC}$, the payback period based on transient operation is less than 5 yrs. A review of the design guidelines by Yuan, et. al., (2001) and Novoselac \& Srebric (2002) emphasized the universal method for determining vertical temperature gradient and desired minimum stratification height in the space. Ayoub, et. al., (2006) developed a simplified thermal transport model for spaces cooled by the combined CC system and tested the applicability with satisfactory results. They suggested that energy consumption using chilled ceiling depended on the supply air temperature, the outdoor airflow rate, conditions, and the cooling load.The system also needs a ventilation system to maintain indoor air quality.

To satisfy these requirements, a combination of radiant cooling with a dehumidification and ventilation system should be considered. As $100 \%$ of the cooling capacity cannot be met by in tropical climates, it is necessary to provide supplementary cooling by dehumidified and cooled ventilation air. However, there is a need to optimise the critical parameters of the hybrid system for instance ceiling temperature, ventilation air temperature (dry and wet bulb temperature) and supply volume flow rate in relation to the space cooling load and comfort criteria (Ameen, 2005).

\section{Desiccant Cooling}

Desiccant cooling is an environmentally friendly system and is preferred in recent years due to global warming and other environmental problems. Over the years, various aspects of desiccant cooling have been investigated to establish its effectiveness as environmental friendly and economical alternative to the traditional systems, which are based on vapour compression cycles with respect to system parameter, climatic condition and loads (Halliday, et. al., 2002). In HVAC system combining chilled-ceiling with desiccant cooling, air dehumidification is required to maintain the indoor air humidity within a comfort zone and to reduce the risk of water condensation on chilled panels in hot and humid climates. Niu, et. al., (2002) evaluated the system performance using chilled-ceiling with desiccant cooling and the energy savings potential by comparing with another three systems such as conventional all-air system, all-air system with total heat recovery, and radiant cooling with air handling unit (AHU) of a typical office. The results indicate that chilled-ceiling combined with desiccant cooling could save up to $44 \%$ of primary energy consumption, in comparison with a conventional constant volume all-air system. More interestingly, more than $70 \%$ of annual operating hours for desiccant regeneration could be accomplished by low-grade heat of less than $80^{\circ} \mathrm{C}$. Hirunlabh, et. al., (2005) conducted an experimental analysis to investigate the performance and energy savings of the desiccant air conditioning systems. Under test bed condition, electricity savings was about $24 \%$ using $15 \%$ of outdoor air, $15 \%$ of return air (mixed with desiccant bed inlet) and $70 \%$ of indoor air (mixed o the dry air leaving the desiccant) ratio.

Among several technologies available for air dehumidification, desiccant cooling is an attractive alternative. In past 10 years, there have been many researches on this technology (Waugaman, et. al., 1993) since it satisfies the demands of the industry for a diversification of primary energy sources and a reduction in the use of CFCs. Hybridization of these systems has the potential to be an economically proposition. In such application, air conditioning can be carried out by humidifying the air through desiccant (solid or liquid) followed by sensible cooling using water and then by an evaporator coil of a conventional vapour compression refrigeration cycle. The regeneration of the desiccant can be accomplished by condenser heat using low grade heat source for instance, solar energy or waste heat recovery from system. Furthermore, regeneration of the desiccant is possible, even at temperature between $60^{\circ} \mathrm{C}$ and $100^{\circ} \mathrm{C}$ which can be supplied by ordinary flat plate solar collector (Ameen, 2005).

To facilitate the applications of radiant cooling to subtropical climates, a system combining chilled- 
ceiling with desiccant cooling can be used. According to this concept, the sensible load is primarily treated by ceiling panels and the latent load and ventilation is accomplished by an auxiliary desiccant cooling system. Niu, et. al., (2002) found that chilledceiling saves much fan energy due to reduced air volume, and saves much chiller energy due to raised evaporating temperatures. Dehumidification by desiccant cooling saves much sensible energy due to the cancellation of reheat processes that are common with dew-point dehumidification. Much thermal comfort can be resulted from chilled ceiling with desiccant cooling. Chilled-ceiling combined with desiccant cooling could save up to $44 \%$ of primary energy, in comparison with a constant volume allair system. Total heat recovery could save $8 \%$ of potential energy when employed in a conventional all-air system. In addition, with chilled-ceiling, temperature and humidity control have been decoupled by using desiccant wheel for moisture removal and ceiling for temperature control. Desiccant cooling could be driven by low-grade thermal heat below $80^{\circ} \mathrm{C}$, suggested a feasibility of applications of renewable energy to air dehumidification with chilledceiling combined with desiccant cooling. Zhand \& Niu (2003) reported chilled ceiling saves much fan energy due to reduced air volume and saves much chiller energy due to raised evaporating temperature compared to all air systems. Total energy savings amount to $47 \%$ with an AHU dehumidification and $30 \%$ with a desiccant dehumidification system. Mezzei, et. al., (2002) obtained up to 35\% savings on investment cost in summer season with reduction in thermal cooling power up to $52 \%$ by using three software codes for a retail shop. Dai et al. (2001) reported an experimental study of a hybrid air conditioning system comprising section of desiccant dehumidification, evaporative cooling and vapour compression air conditioning having 20-30\% higher cooling capacity than the vapour compression system alone. Dhar and Singh (2001) presented the performance of four hybrid cycles for typical hot-dry and hot-humid weather conditions for the analysis of rotary dehumidifier. Henning, et. al., (2001) claimed that the combination of absorptive dehumidification with a conventional, electrically driven backup system allows for primary energy savings up to $50 \%$ at low increased overall cost.

Unlike conventional air conditioning system, which requires higher degree energy to run cooling cycle, desiccant cooling is heat driven cycle. Although starting costs of the desiccant system are generally higher with respect to traditional summer operating costs of traditional air conditioning system, the costs can be slightly minimised using de-rated system. Utilisation of integrated evaporative cooling for desiccant system and packaged total gas solid desiccant systems present high energy savings with a capability to allow better indoor thermal comfort. However, operating cost savings obtainable with desiccant systems depend on local climatic conditions, energy rates and overall performance of the desiccant wheel.

\section{Thermal Storage Air Conditioning}

Electric utility companies usually encourage the use of Thermal Storage Air Conditioning (TSAC) systems to reduce the cost required to generate peak electric power and has become well established in many countries like USA, Japan and Taiwan etc. Indeed, demand during peak hours can be eliminated by using off peak power. Utility companies have initiated different rate structures to penalize the use of peak hour electric power. In addition to the peak and off-peak energy rates, utility companies have imposed demand charges, based on the monthly peak demand. Most utilities offer rate incentives to encourage customers to consider TSAC which substantially lower life cycle cost, particularly due to longer equipment and system life (Dorgan \& Elleson, 1994).

\section{Conclusions}

The result of the implementation of energy efficiency strategies in building for better sustainability give improved indoor environmental quality, economic benefits, reduced pollution in both the local and global environment. When all energy performance and indoor climate standards are met and the proper quality of service is assured, the approaches to building's sustainability are developed. Technologies have afforded designers with artificial methods of providing comfort. That does not mean that weather patterns should be ignored. Often, the effort required for a climate-responsive design is not focused on technology so much as on initial consideration of a particular climate's challenges and opportunities, as well as methodical analysis of how different design strategies work in that climate's context. This simplicity when combined with climatic common sense allows buildings to work with. The above discussion shows define assurance of sustainability of buildings under subtropical climate condition. Although HVAC systems offer many opportunities for recovery of thermal energy, it is preferred to use less energy at first instance by efficient system through improved operating procedure from sustainability point of view. Techniques such as mixed mode ventilation, thermal storage based air conditioning, radiant cooling, desiccant cooling, and passive solar cooling are important in terms of energy use and indoor environment of building. Energy efficient approach enables building to reduce energy consumption, improve the working environment, reduce impacts of 
building operation, and in the end ensure sustainability of the buildings and suburban environment. To ensure this, HVAC systems have an important role to play since many factors for efficient performance directly or indirectly have affected by the performance of the HVAC systems. An integrated approach is required to optimise assets operation for efficient building performance. A few HVAC technologies have been reviewed in the paper and currently many of those are being used successfully with performance improvements to cut operating cost and accelerate integration of the new systems within conventional HVAC systems. Different technologies reviewed in the paper can contribute to improve thermal performance of buildings with a decrease of cooling load. Combination of those strategies can further decrease cooling loads and develop energy efficient sustainable building of twenty first century.

The previous work suggests that Displacement Ventilation is feasible for subtropical Queensland through out the year and it will use less energy compared to traditional system. Only limitation is that it can work with small load. Pre-cooling and Night Ventilation have prominent features in subtropical Queensland for passive cooling. The weather data shows that the average night temperature (highest $22^{\circ} \mathrm{C}$ and lowest $9.4^{\circ} \mathrm{C}$ ) is suitable for precooling and Night Ventilation. A recent simulation study by Chowdhury, et. al., (2007) found that precooling conserved night-time traditional cooling cost and offered comfortable natural environment to the occupants. Complex control strategies are not required to maintain comfortable condition. The precooling will also reduce the starting load requirement of the building thermal mass thus offer saving towards peak demand charge. Cooling inside the buildings can be improved by the application of such cooling design.

Radiant cooling can be applied in subtropical climate because cooling required for certain period of time specially at day time and usually needs low heat gain to be cooled to achieve thermal comfort. As suggested by Vangtook \& Chirarattananon (2005), cooling tower can be employed to provide cooling water for radiant cooling and for pre-cooling of ventilation air to achieve thermal comfort. No active cooling is required. For sophisticated condition, precooling ventilation air with cooling water generated from active cooling can help to achieve thermal comfort superior to the case of conventional air conditioning. Substantial energy saving can still be achieved. Chowdhury, et. al., (2006) utilised the application of the chilled ceiling technique in an office building and demonstrated the potential savings as a low energy cooling technology in a subtropical Queensland climate. It improved thermal comfort and reduced the energy consumption of the building. In cases where cooling panels cannot influence air temperature sufficiently, it helps to reduce radiant temperature.

Desiccant cooling is also an established low energy cooling system .It has got very good track record over the years by the researchers. For subtropical Queensland, it will also offer substantial monetary savings. To facilitate the applications in subtropical climate a system combining chilled ceiling with desiccant cooling is preferred for Rockhampton. It will save fan and chiller energy due to reduced air volume and raised evaporative temperature. Dehumidification by desiccant cooling will conserve much sensible energy and much more thermal comfort will result. If the system combining chilled ceiling with air dehumidifier is maintained, the temperature and indoor humidity are decoupled and human comfort can be controlled independently.

Excessive energy consumption causes damage to eco-environment and leads to abnormality from a socio-economic point of view. Globally buildings are responsible for a large portion of the total world's annual energy consumption. In addition, most of this energy is for the functioning of lighting, heating, cooling and air conditioning. Concerns about social and environmental sustainability have led to increased interest in planning for proper utilisation of energy. World's attention on current climate change impact and sustainability has situated for a closer look at the energy efficient technologies. As buildings are important consumer of energy and thus important contributor to the higher greenhouse gas emissions to the environment. Energy use reduction can be achieved by minimising the energy demand, by rational energy use, by recovering heat and the use of more passive means for low energy use. Therefore, low energy cooling technologies for buildings must be one of the definite alternatives to contribute to the sustainability of buildings. This study is a step towards achieving this goal.

\section{References}

Alamdari, F, D J G Butler, P F Grigg, and M R Shaw. "Chilled Ceiling and Displacement Ventilation.” Renewable Energy 15 (1998): 300-305

Ameen, A. "The Challenges of Air-Conditioning in Tropical and Humid Tropical Climates." Proceedings of the International Conference on Mechanical Engineering (ICME). Dhaka: Bangladesh University of Engineering and Technology, 2005. 
Ayoub, M, N Ghaddar, and K Ghali. "Simplified thermla model of spaces cooled with combined chilled ceiling and displacement ventilation system." ASHRAE International Journal of HVAC\&R Reseach 12, no. 4 (2006): 57-83.

Becker, R, and M Paciuk. "Inter-related Effects of Cooling Strategies and Building Features on Energy Performance of Office Buildings." Energy and Buildings 34 (2002): 25-31.

Blondeau, P, M Spe'randio, and F Allard. "Night ventilation for building cooling in summer." Solar Energy 61, no. 5 (1997): 327-335.

BOM. “Climate Information.” Bureau of Meteorology . 2007. http://www.bom.gov.au/climate/.

Chowdhury, A A, M G Rasul, and M M K Khan. "Low Energy Cooling Technologies for Subtropical/Warm Humid Building Systems.” SimBuild 2006, Conference on Building Sustainability and Performance Through Simulation. Cambridge, MA: International Building Performance Simulation Association (IBPSA) - USA, 2006.

Chowdhury, A A, M G Rasul, and M M K Khan. "Modelling and Simulation of the Effects of Passive Cooling Technologies on Energy Savings for Building Systems in Subtropical Climate." In Mathematics and Computers in Science and Engineering, by Siavash H Sohrab, Haris J Catrakis, Nikolai Kobasko and Necasova Sarka, 72-77. Athens, Greece: World Scientific and Engineering Academy and Society, 2007.

Clift, Roland. "Climate Change and Energy Policy: The Importance of Sustainability Arguments." Energy 32 (2007): 262268.

Dai, Y J, R Z Wang, H F Zhang, and J D Yu. "Use of Liquid Desiccant Cooling to Improve the Performance of Vapour Compression Air Conditioning." Applied Thermal Engineering 21 (2001): 1185 - 1202.

Dhar, P L, and S K Singh. "Studies on Solid Desiccant Based Hybrid Air Conditioning Systems." Applied Thermal Engineering 21, no. 2 (2001): 119 - 134.

Dorgan, C E, and J E Elleson. Design Guide for Cool Thermal Storage. Atlanta: American Society of Heating, Refrigerating, and Air Conditioning Engineers, Inc., 1994.

ESAA. "Energy Supply Association of Australia." 2007. http://www.esaa.com.au/.

Feustel, H E, and C Stetiu. "Hydronic radiant cooling-primary assessment." Energy and Building 22, no. 3 (1995): $193-205$.

$\mathrm{Fu}, \mathrm{X}, \mathrm{Z}$ Gao, and S Kang. "Residential aeration cooling in Chang Jiang River Basin." Heating Ventilating \& Air Conditioning 03 (1996): 27-29.

Geros, V, M Santamouris, A Tsangrasoulis, and G Guarracino. "Experimental Evaluation of Night Ventilation Phenomena." Energy and Buildings 29 (1999): 141-154.

Ghali, K, N Ghaddar, and M Ayoub. "Chilled ceiling and displacement ventilation system for energy savings : A case study." International Journal of Energy Research 31 (2007): 743-759.

Halliday, S, C B Beggs, and P A Sleigh. "The Use of Solar Desiccant Cooling in the UK: A Fesibility Study." Applied Thermal Engineering 22 (2002): 1327-1338.

Henning, H M, T Erpenbeck, C Hindenburg, and I S Santamaria. "The Potential of Solar Energy Use in Desiccant Cooling Cycle." International journal of Refrigeration 44 (2001): 220 - 229.

Hirunlabh, J, R Charoenwat, J Khedari, and S Teekasap. "Feasibility Study of Desiccant Air-Conditioning System in Thailand." Building and Environment 42, no. 2 (2007): 572-577.

Imanari, T, T Omori, and K Bogaki. "Thermal Comfort and Energy Consumption of the Radiant Ceiling Panel System: Comparison with the Conventional All Air System.” Energy and Buildings 30 (1999): 167 - 175.

ISO, 7730. "Moderate Thermal Environments-Determination of the PMV and PPD Indices and Specification of the Conditions for Thermal Comfort.” Geneva: International Standards Organisation, 1994.

Kilkis, B I. "Coolp: a computer program for the design and analysis of ceiling cooling panels." ASHRAE Transactions 101, no. 2 (1995): 703-710.

Kolokotroni, M. "Night ventilation for cooling field tests and design tools." In Low-Energy Cooling Technologies for Buildings: Challenges and Opportunities for the Environmental Control of Buildings, 33-44. London: Professional Engineering Publishing, 1998.

Kolokotroni, M, and A Aronis. "Cooling-energy reduction in air-conditioned offices by using night ventilation." Applied Energy 63, no. 4 (1999): 241-253.

Levermore, G J. Building Energy Management Systems: Applications to Low Energy HVAC and Natural Ventilation Control. London: Taylor \& Francis, 2000.

Lin, Zhang, T T Chow, K F Fong, Qiuwang Wang, and Ying Li. "Comparison of Performances of Displacement and Mixing Ventilations. Part I: Thermal Comfort.” International Journal of Refrigeration 28, no. 2 (2006): 276-287.

Loveday, D L, K C Parsons, A H Taki, and S G Hodder. "Displacement Ventilation Environments with Chilled Ceilings, Thermal Comfort Design within the Context of the BS EN ISO7730 Versus Adaptive Debate." Energy and Buildings 34 (2002): 573-579.

Lutzkendorf, T, and D Lorenz. "Sustainable Property Investment: Valuing Sustainable Buildings through Property Performance Assessment." Building Research and Information 33, no. 3 (2005): 212-234.

Mazzei, P, F Minichiello, and D Palma. "Desiccant HVAC System for Commercial Buildings." Applied Thermal Engineering 22 (2002): 545 - 560.

Mertz, G. "Chilled Ceilings and Ventilating Systems - Thermal Comfort and Energy Saving." Air Infiltration Review 13, no. 3 (1992): 7-19.

Mumma, Stanley A. "Condensation Issues with Radiant Cooling Panels.” IAQ Applications (ASHRAE), 2001: 1-3.

Mumma, Stanley A. “Overview of Integrating Dedicated Outdoor Air Systems With Parallel Terminal Systems.” ASHRAE Transactions 107, no. 1 (2001): 545-552. 
Niu, J L, J Kooi, and H Ree. "Eergy Saving Possibilities with Cooled-Ceiling Systems.” Energy and Buildings 23, no. 2 (1995): 147-158.

Niu, J, and et al. "Cooling load dynamics of rooms with cooled ceilings." Building Services Engineering Research \& Technology 18, no. 4 (1997): 201-207.

Novoselac, A, and J Srebric. "A critical review on the performance and design of combined cooled ceiling and displacement ventilation systems." Energy and Buildings 34 (2002): 497-509.

Rees, S J, and P Haves. "A Nodal Model for Displacement Ventilation and Chilled Ceiling Systems in Office Spaces." Building and Environment 36 (2001): 753-762.

Riffat, S B, X Zhao, and P S Doherty. "Review of research into and application of chilled ceilings and displacement ventilation systems in Europe." International Journal of Energy Research 28 (2004): 257-286.

San-Jose, J T, R Losada, J Cuadrado, and I Garrucho. "Approach to the Quantification of the Sustainable Value in Industrial Buildings.” Building and Environment 42 (2007): 3916-3923.

Sarja, A. Integrated Life Cycle Design of Structure. London: Spon Press, 2002.

Shaviv, E, A Yezioro, and I G Capeluto. "Thermal Mass and Night Ventilation as Passive Cooling Design Strategy." Renewable Energy 24, no. 3-4 (2001): 445-452.

Sprecher, P, and et al. "Chilled ceiling for hot heads." Sulzer Technical Review 20, no. 1 (1996): 15-17.

Todd, J A, D Crawley, S Geissler, and G Lindsey. "Comparative Assessment of Environmental Performance Tools and the Role of the Green Building Challenge." Building Research and Information 29, no. 5 (2001): 324-335.

Trox. "Building Design optimization with Underfloor Air Distribution in the San Francisco area." Alpharetta, GA: Trox (USA), 1997.

Udagawa, M. "Simulation of panel cooling systems with linear subsystem." ASHRAE Transactions 99, no. 2 (1993): 534-544.

Waugaman, D G, A Kini, and C F Kettleborough. "A Review of Desiccant Cooling Systems.” ASME Journal of Energy Resources Technology 115 (1993): 1-8.

Wikipedia. "Green Building.” 2007. http://en.wikipedia.org/wiki/Green building (accessed October 2007).

Wilkins, C K, and R Kosonen. "Cool ceiling system: A European Air-Conditioning Alternative,." ASHRAE Journal August (1992): 41-45.

World Business Council for Sustainable Development. Energy Efficiency in Buildings: Business Realities and Opportunities. 2007. (accessed September 9, 2007).

Yuan, X, Q Chen, and L Glicksman. "A Critical Review of Displacement Ventilation." ASHRAE Transactions 41, no. 01 (2001): 78-90.

\section{About the Authors}

Ashfaque Ahmed Chowdhury

Ashfaque Ahmed Chowdhury is working as a research scholar in the College of Engineering and Built Environment, Faculty of Sciences, Engineering and Health, Central Queensland University, Australia. His research interest includes asset management, building performance simulation, smart building systems, building condition monitoring, maintenance and intelligent control systems, mechatronics, CNC manufacturing,. He obtained his Bachelor of Science in Mechanical Engineering from Islamic University of Technology (IUT), a subsidiary organ of the Organisation of Islamic Conference (OIC), Gazipur, Bangladesh in 2003. In 2005, he moved to Australia to pursue research higher degree at Central Queensland University (CQU). He worked as a lecturer at Islamic University of Technology, Bangladesh and Central Queensland University, Australia. He has published 15 research articles in international journals and conferences. He is an active member of the International Building Performance Simulation Association (IBPSA) - Australasia, the Modeling and Simulation Society of Australia and New Zealand (MSSANZ), the International Association of Engineers (IAENG) - UK, and the Australasian Association for Engineering Education (AAEE).

Dr. M.G. Rasul

Mohammad G. Rasul graduated in Mechanical Engineering from Bangladesh University of Engineering and Technology (BUET), Dhaka, Bangladesh in 1987. He completed his Master of Engineering in Energy Technology from Asian Institute of Technology (AIT), Bangkok, Thailand, in 1990. He obtained PhD on Energy and Thermodynamics from The University of Queensland, Australia, in 1996. Currently, he is working as a Senior Lecturer in Mechanical Engineering and Head of the Department of Sustainability at College of Engineering and the Built Environment, Faculty of Sciences, Engineering and Health, Central Queensland University, Rockhampton, Queensland 4702, Australia. He is specialised and experienced, and interested in research, teaching and consultancy in the area of thermodynamics and energy, fluid mechanics, process industry's energy and environmental pollution analysis and building energy analysis. Dr Rasul is an author of more than 80 refereed journal and conference papers including few chapters in books. He is an active member of the Engineers Australia and the Australasian Association for Engineering Education. 
Ass. Prof. M.M.K. Khan

M. Masud K. Khan is an Associate Professor and Head of Department of Infrastructures in the Faculty of Sciences, Engineering and Health, Central Queensland University, Rockhampton, Queensland 4702, Australia. He received his MS (Mech) with 1st class Honours from Moscow Institute of Petrochemical and Gas Industry in 1982. Subsequently he worked with the oil industry for 2 years. He obtained his $\mathrm{PhD}$ in engineering from the University of Sydney in 1990. His teaching, research and consulting activities are in the area of non-Newtonian fluid mechanics, thermofluid engineering and rheology of industrial fluids and polymeric materials. He has authored more than 95 refereed journal, conference and technical papers. He is a member of American Society of Rheology, Australian Society of Rheology, Engineers Australia and the Australasian Association for Engineering Education (AAEE). 
Amareswar Galla, The University of Queensland and Director, Pacific Asia Observatory for Cultural Diversity in Human Development.

Mary Kalantzis, University of Illinois, Urbana-Champaign, USA.

\section{EDITORIAL ADVISORY BOARD}

Shamsul Nahar Abdullah, University of Malaysia Terengganu, Malaysia.

Wan Izatul Asma, University of Malaysia Terengganu, Malaysia.

Dang Van Bai, Department of National Cultural Heritage, Ministry of Culture and Information, Vietnam.

Richard M. Clugston, Center for the Respect of Life and the Environment, and University Leaders for a Sustainable Future, Washington DC, USA.

Bill Cope, University of Illinois, Urbana-Champaign, USA; Common Ground.

John Dryzek, Research School of Social Sciences, Australian National University, Canberra, Australia.

Robyn Eckersley, Department of Political Science, University of Melbourne, Australia.

Steven Engelsman, Rijksmuseum voor Volkenkunde, The Netherlands. John Fien, RMIT University, Melbourne, Australia.

Steve Hamnett, University of South Australia, Australia.

Paul James, Globalism Institute, RMIT University, Melbourne, Australia.

Mary Kalantzis, University of Illinois, Urbana-Champaign, USA.

Nik Fuad Nik Mohd Kamil, University of Malaysia Terengganu, Malaysia.

Lily Kong, National University of Singapore, Singapore.

Thangavelu Vasantha Kumaran, University of Madras, India.

Jim McAllister, Central Queensland University, Australia.

Nik Hashim Nik Mustapha, University of Malaysia Terengganu, Malaysia.

Helena Norberg-Hodge, The International Society for Ecology and Culture (ISEC).

Peter Phipps, Globalism Institute, RMIT University, Melbourne, Australia.

Koteswara Prasad, University of Madras, India.

Behzad Sodagar, Lincoln School of Architecture, University of Lincoln, Brayford Pool, Lincoln, United Kingdom

Judy Spokes, Cultural Development Network, Melbourne, Australia.

Manfred Steger, Illinois State University, and The Globalism Institute, RMIT University, Melbourne, Australia.

David Wood, University of Waterloo, Canada.

Lyuba Zarsky, Globalism Institute, RMIT, Australia, and Global Development and Environment Institute, Tufts University, United States. 


\title{
THE UNIVERSITY PRESS JOURNALS
}

\author{
International Journal of the Arts in Society \\ Creates a space for dialogue on innovative theories and practices in the arts, and their inter-relationships with society. \\ ISSN: 1833-1866 \\ http://www.Arts-Journal.com
}

International Journal of the Book

Explores the past, present and future of books, publishing, libraries, information, literacy and learning in the information society. ISSN: 1447-9567

http://www.Book-Journal.com

Design Principles and Practices: An International Journal

Examines the meaning and purpose of 'design' while also speaking in grounded ways about the task of design and the use of designed artefacts and processes. ISSN: 1833-1874 http://www.Design-Journal.com

International Journal of Diversity in Organisations, Communities and Nations

Provides a forum for discussion and builds a body of knowledge on the forms and dynamics of difference and diversity. ISSN: $1447-9583$

http://www.Diversity-Journal.com

International Journal of Environmental, Cultural, Economic and Social Sustainability

Draws from the various fields and perspectives through which we can address fundamental questions of sustainability. ISSN: 1832-2077

http://www.Sustainability-Journal.com

Global Studies Journal

Maps and interprets new trends and patterns in globalization. ISSN 1835-4432

http://www.GlobalStudiesJournal.com

International Journal of the Humanities

Discusses the role of the humanities in contemplating the future and the human, in an era otherwise dominated by scientific, technical and economic rationalisms. ISSN: 1447-9559

http://www. Humanities-Journal.com

International Journal of the Inclusive Museum

Addresses the key question: How can the institution of the museum become more inclusive? ISSN 1835-2014 http://www.Museum-Journal.com

International Journal of Interdisciplinary Social Sciences

Discusses disciplinary and interdisciplinary approaches to knowledge creation within and across the various social sciences and between the social, natural and applied sciences.

ISSN: 1833-1882

http://www.Socialsciences-Journal.com

International Journal of Knowledge, Culture and Change Management

Creates a space for discussion of the nature and future of organisations, in all their forms and manifestations.

ISSN: $1447-9575$

http://www.Management-Journal.com

International Journal of Learning

Sets out to foster inquiry, invite dialogue and build a body of knowledge on the nature and future of learning.

ISSN: $1447-9540$

http://www.Learning-Journal.com

International Journal of Technology, Knowledge and Society

Focuses on a range of critically important themes in the various fields that address the complex and subtle relationships between technology, knowledge and society. ISSN: 1832-3669 http://www.Technology-Journal.com

Journal of the World Universities Forum

Explores the meaning and purpose of the academy in times of striking social transformation. ISSN 1835-2030

http://www.Universities-Journal.com

\author{
FOR SUBSCRIPTION INFORMATION, PLEASE CONTACT \\ subscriptions@commonground.com.au
}

